\title{
Agaricales of the dunes of Galicia (IV): Marasmiellus ciesanus (Omphalotaceae), a new species found in the National Maritime- Terrestrial Park of the Atlantic Islands of Galicia (Spain)
}

\author{
Blanco-Dios JB $\mathbf{~}^{1}$ \\ ${ }^{l}$ Centro de Formación e Experimentación Agroforestal de Lourizán. Consellería de Medio Rural e do Mar. Xunta de \\ Galicia. P.O. Box 127. 36080 Pontevedra,Spain
}

Blanco-Dios JB 2015 - Agaricales of the dunes of Galicia (IV): Marasmiellus ciesanus (Omphalotaceae), a new species found in the National Maritime-Terrestrial Park of the Atlantic Islands of Galicia (Spain). Mycosphere 6(5), 585-592, Doi 10.5943/mycosphere/6/5/7

\begin{abstract}
Marasmiellus ciesanus, collected in open dunes in the National Maritime-Terrestrial Park of the Atlantic Islands of Galicia, is illustrated and described as a new species from Spain on the basis of morphological features. This species is close to other taxa of the subsection Quercini, in which it occupies an isolated position due to its unusual small spores broadly ellipsoid to oblong-lacrimoid, versiform cheilo- and caulocystidia and specific substrata (dead stalks of Helichrysum picardii var. virescens).
\end{abstract}

Key words - Basidiomycota - Omphalotaceae - Marasmiellus - National Park - Cies - Spain taxonomy.

\section{Introduction}

During the last decades of intensive research of Galician macromycetes, a significant number of rare and new taxa has been found. Some of these have been published in the last years in a series of papers under the title "Agaricales de las dunas de Galicia (Agaricales des dunes de Galice)" (Blanco-Dios 2001,2010,2014).

Marasmiellus Murrill (Omphalotaceae, Agaricales) is a tropical and subtropical genus which consists of more than 400 species (Wilson \& Desjardin 2005), widespread all over the world, especially in the tropics, and is a genus traditionally included in the Tricholomataceae family (Singer 1986). Later it was transferred to the Marasmiaceae Roze ex Kuhner (Kirk et al. 2008). According to DNA studies, however, it belongs to the Omphalotaceae (Moncalvo et al. 2002, Wilson \& Desjardin 2005). Some species are found on living hosts, but more often they occur on dead and rotting plant material, and some are host specific.

The genus Marasmiellus was first established by Murrill (1915) with a very simple descriptions: " Pileus small, irregular in shape, membranous, reviving, lamellae adnate or adnexed, basidiospores hyaline, partial veil absent, stipe filiform, tubular, short, lateral or eccentric". Later, Singer (1973) wrote more complete descriptions which defined the genus concept more clearly: "Basidiocarp small to medium. Pileus $0.3-3 \mathrm{~cm}$, marasmioid-collybioid, collybioid-mycenoid, or sometimes pleurotoid, white, greyish white, reddish brown or dark brown. Lamellae attached, slightly decurrent, intervenose. Stipe central, eccentric, lateral or no stipe, insititious or 
subinsititious, rarely base tomentose. Basidiospores white to off-white, ellipsoid, oblong, smooth, inamyloid. Pileipellis or stipipellis composed of Rameales-structures". According to Singer (1973,1986), the genus Marasmiellus was divided into 10 sections: Defibulati, Nigripedes, Tetrachroi, Stenophylloides, Candidi, Dealbati, Tricholores, Rameales, Distantifolii and Marasmiellus. Separation of these infrageneric classifications of Marasmiellus taxa depends on recognition of a combination of macromorphological and micromorphological characters, i.e. type of pileipellis (Rameales-structure, cutis with or without diverticulate), presence or absence of cheilocystidia, basidiospores sizes, stipe attachment (central, eccentric), and pileus color (pigment or non-pigmented), etc. (Retnowati 2012). The sect. Nigripedes was later segregated by Horak (1987) in the new genus Tetrapyrgos E.Horak (= Pterospora Métrod, 1949, nom. ill.), genus characterized by tetrahedral spores or with a conspicuous lateral bulge, by cheilocystidia and pileocystidia that are diverticulate and often with a capitate terminus, and a pileipellis of densely diverticulate hyphae. This taxonomic placement was supported by Wilson \& Desjardin (2005) based on molecular data (nLSU rDNA sequences).

Several monographs of the genus Marasmiellus have been published based on morphological data. Singer (1973) described 134 species of Neotropical Marasmiellus. This monograph is the most complete published paper on Marasmiellus, and it becomes a basic reference for taxonomic work of this genus. Pegler $(1977,1983,1986)$ made a significant contribution by publishing several monographs from different regions, by reporting 14 described species of Marasmiellus of East Africa (Pegler 1977), describing 23 species from Lesser Antilles (1983), and 17 species from Sri Lanka (Pegler 1986). Twenty one species of Marasmiellus were described by Antonín \& Noordeloos (1993) and 26 taxa in Antonín \& Noordeloos (2010) from Europe, most of them are widespread, cosmopolitan, with numerous species in the subtropic. The species so far known are usually gregarious, saprobic, more rarely phytoparasitic, and grow on all kinds of plants, and in some cases they are host-specific (Singer 1973, 1976 [1975], 1986, 1989, Pegler 1977, 1983, 1986, Corner 1996, Desjardin 1985, 1987, 1997, Desjardin et al. 1992, Antonín \& Noordeloos 1993, 2010, Grgurinovic 1997, Takahashi \& Degawa 2006, Antonín et al. 2010, Pérez-De-Gregorio et al. 2011, Retnowati 2012).

Many species of Marasmiellus occur in habitats with high variability in moisture availability, and some taxa are salt-tolerant. For these reasons, members of the genus are often encountered in coastal environments. Some species are specific of dune vegetation or other coastal habitats, e.g. $M$. brevisporus (Maire) Contu, M. celebanticus Pérez-De-Greg., Vizzini, Contu \& C. Roqué, M. maritimus Contu \& Noordel. and M. trabutii (Maire) Singer, (Contu 2008, Antonín \& Noordeloos 2010, Pérez-De-Gregorio et al. 2011). In this group of species typical of coastal environments, the new species of Marasmiellus described and illustrated in this work, found in the National MaritimeTerrestrial Park of the Atlantic Islands of Galicia (PNMTIAG), grows on dead stalks of Helichrysum picardii var. virescens Valdés-Berm. (Compositae).

\section{Materials \& Methods}

Macroscopic descriptions of collected specimens are based on the study of fresh basidiocarps. The specimens were collected, documented and preserved using standard methods. Basidiomes photographs were taken in situ with digital camera. For lamellae, L stands for the number of entire lamellae and 1 for the number of lamellulae between each pair of entire lamellae. Microscopic observations were recorded on dried material with standard methods, using sections mounted in a solution of $1 \%$ Congo Red in water after a short pre-treatment in a 5\% potassium hydroxide solution, in Melzer's reagent, in $10 \% \mathrm{NH}_{4} \mathrm{OH}$ or in $1 \%$ Cresyl blue. Basidiospores measurements (length, width, Q (quotient length/width), Qm = average quotient), were taken for 30 basidiospores. Microscopic structures were drawn with help of a drawing tube. Author citations follow the IPNI Authors Website (http://www.ipni.org/ipni/authorsearchpage.do) and the Index Fungorum Authors of Fungal Names Website (http://www.indexfungorum.org/authorsoffungalnames.htm). The new species name was deposited in MycoBank (http://www.mycobank.org/DefaultPage.aspx). Herbarium abbreviations are according to Thiers (2015). The collected material has been deposited 
in the mycological herbarium LOU-Fungi (Centro de Investigación Forestal de Lourizán, Consellería de Medio Rural e do Mar, Pontevedra, Spain).

\section{Results}

Marasmiellus ciesanus Blanco-Dios, sp. nov.

Figs. 1-8

MycoBank: MB 812737

Etymology - ciesanus, from the Cies Islands (Galicia, Spain).

Pileus 6-12 mm latus, hemisphaericus usque ad planum, saepe ad medium depressus et umbonatus, minute fibrillosus, centro subtiliter pruinosus, ochraceus, ad medium brunneus, margine cremeus vel albidus. Lamellae distantes, interdum furcatae, albidae, adnatae vel adnatosubdecurrentes. Stipes 5-8 × 0.5-2 mm, centralis, cylindraceus sed saepe ad basim incrassatus, ochraceus vel brunneus ad apicem, ab nigro-griseus ad nigrum versus basim, pruinosus-floccosus omnino obtectus. Caro parce conspicua, haud gelata, albida, immutabilis. Odor saporque grato. Sporis (3-)4-5.5 × (2-)2.5-3.5(-4) $\mu \mathrm{m}, Q=1.31-1.80$ (2.20), Qm=1.57, ab late ellipsoideis ad oblongo-lacrimiformis, tenuitunicatis, hyalinis, inamyloideis. Basidiis $18-33 \times 6.5-13 \mu m$, tetrasporigeris, clavatis. Cheilocystidiis 9.5-47 × 4.5-10 $\mu \mathrm{m}$, irregulariter flexuosus, utriformis, utriformis-septatus, irregulatim moniliformis vel diversus irregulariter formis (septatus vel aseptatus), tenuitunicatis. Pileipellis in cutis efformatus, hyphis cylindraceis vel subcylindraceis, 4$14 \mu \mathrm{m}$ latis; elementis terminalis 10-52 × 2-12 $\mathrm{m}$, clavatis, lecithiformis, irregulariter cylindraceis, capitatus vel irregulatim formis, tenuitunicatis. Stipitipellis in cutis efformatus, hyphis cylindraceis vel subcylindraceis, 1-5 $\mu \mathrm{m}$ latis. Caulocystidiis 13-24 × 3-9.5 $\mu \mathrm{m}$, clavatis, lecithiformis-septatus, irregulariter flexuosus, irregulatim capitatus vel irregulariter formis, tenuitunicatis. Hyphis fibulatis, haud amyloideis vel dextrinoideis. Gregaria ad quisquilias Helichrysum picardii var. virescens.

Holotype - SPAIN. Pontevedra: Vigo, Cíes Islands, Faro island, Rodas beach, 29TNG0874, 5 m, in open dunes, on dead stalks of Helichrysum picardii var. virescens, 14 December 2010, J.B. Blanco-Dios \& A. Castro (LOU-Fungi 19745).

Basidiocarps in groups. Pileus 6-12 $\mathrm{mm}$ broad, hemispherical with plane to slightly depressed centre, then plano-convex with almost applanate to slightly depressed centre and with low and obtuse central umbo within this depression, margin incurved then deflexed or straight, revolute in old specimens, undulated or crenulate, minutely radially fibrillose under lens, especially at pruinose centre, translucently striate when moist, ochre (brown in centre) with paler, cream to whitish margin. Lamellae moderately distant $(\mathrm{L}=16-20, \mathrm{l}=2-6)$, sometimes forked, adnate to adnate-subdecurrent, whitish, with a concolorous, finely pubescent edge. Stipe 5-8 $\times 0.5-2 \mathrm{~mm}$, central, at first stuffed then hollow, cylindrical, often with a broadened base, ochre to brown at apex, blackish-grey towards black base, entirely covered with a persistent, paler pruinose-floccose covering, specially in upper part. Context very thin, tough, not gelatinized, whitish, not changing color; odor and taste mild. Spore print white.

Basidiospores (3-)4-5.5 × (2-)2.5-3.5(-4) $\mu \mathrm{m}, \mathrm{Q}=1.31-1.80$ (2.20), Qm=1.57 ( $\mathrm{n}=30)$, broadly ellipsoid to oblong-lacrimoid, smooth, thin-walled, hyaline, non-amyloid. Basidia 18-33 $\times$ 6.5-13 $\mu \mathrm{m}$, sterigmata up to $5.5 \mu \mathrm{m}$ long, 4-spored, clavate, non-siderophilous, clamped. Basidioles 16-25 $\times 5-7 \mu \mathrm{m}$, subcylindrical or clavate. Cheilocystidia 9.5-47 $\times 4.5-10 \mu \mathrm{m}$, variable in shape: irregularly flexuous, utriform, utriform-septate, abnormally moniliform or others irregularly shaped (septate or not), thin-walled, scattered or in clusters. Pleurocystidia absent. Pileipellis a cutis consisting of cylindrical or subcylindrical hyphae, 4-14 $\mu \mathrm{m}$ wide, thin-walled, non-dextrinoid, without pigment; terminal elements $10-52 \times 2-12 \mu \mathrm{m}$, morphologically highly variable: irregularly cylindrical, clavate, lecithiform, capitate or irregularly shaped, thin-walled. Pileocystidia absent. Trama of pileus and hymenophore irregular, made up of interwoven, non-dextrinoid and thinwalled hyphae, 2-13 $\mu \mathrm{m}$ wide. Stipitipellis a cutis composed of cylindrical or subcylindrical, subparallel or interwoven hyphae, 1-5 $\mu \mathrm{m}$ wide, thin-walled, non-dextrinoid. Caulocystidia 13-24 $\times 3-9.5 \mu \mathrm{m}$, sparse, adpressed to erect, versiform: clavate, irregularly flexuous, lecithiform-septate, 


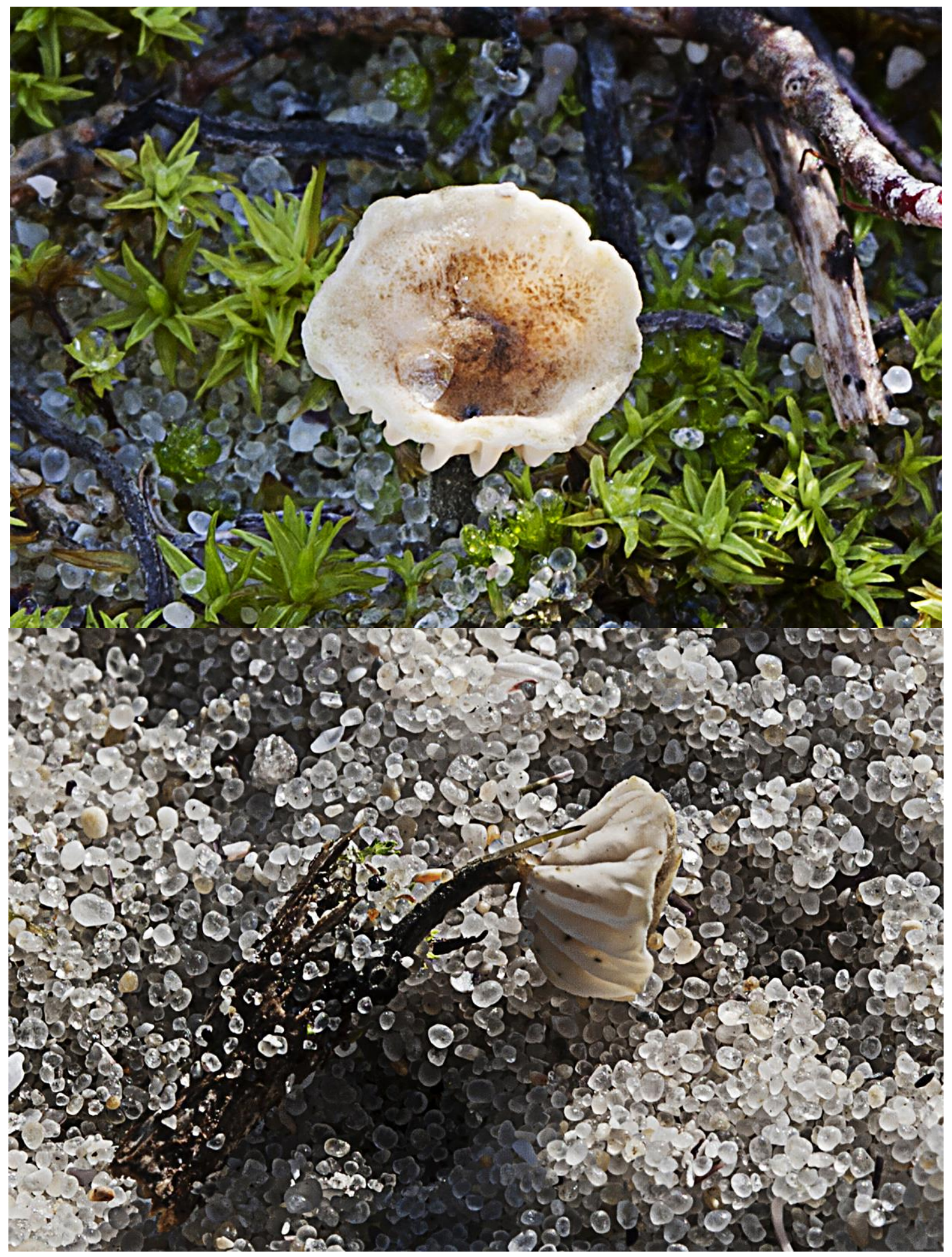

Figs 1-2-Marasmiellus ciesanus. LOU-Fungi 19745 (Holotype). Photos by Amancio Castro.

abnormally capitate or others irregularly shaped, thin-walled. Clamp connections present in all tissues.

Chemical reactions. No part of the basidiocarp shows an amyloid or dextrinoid reaction; not metachromatical in Cresyl blue. 


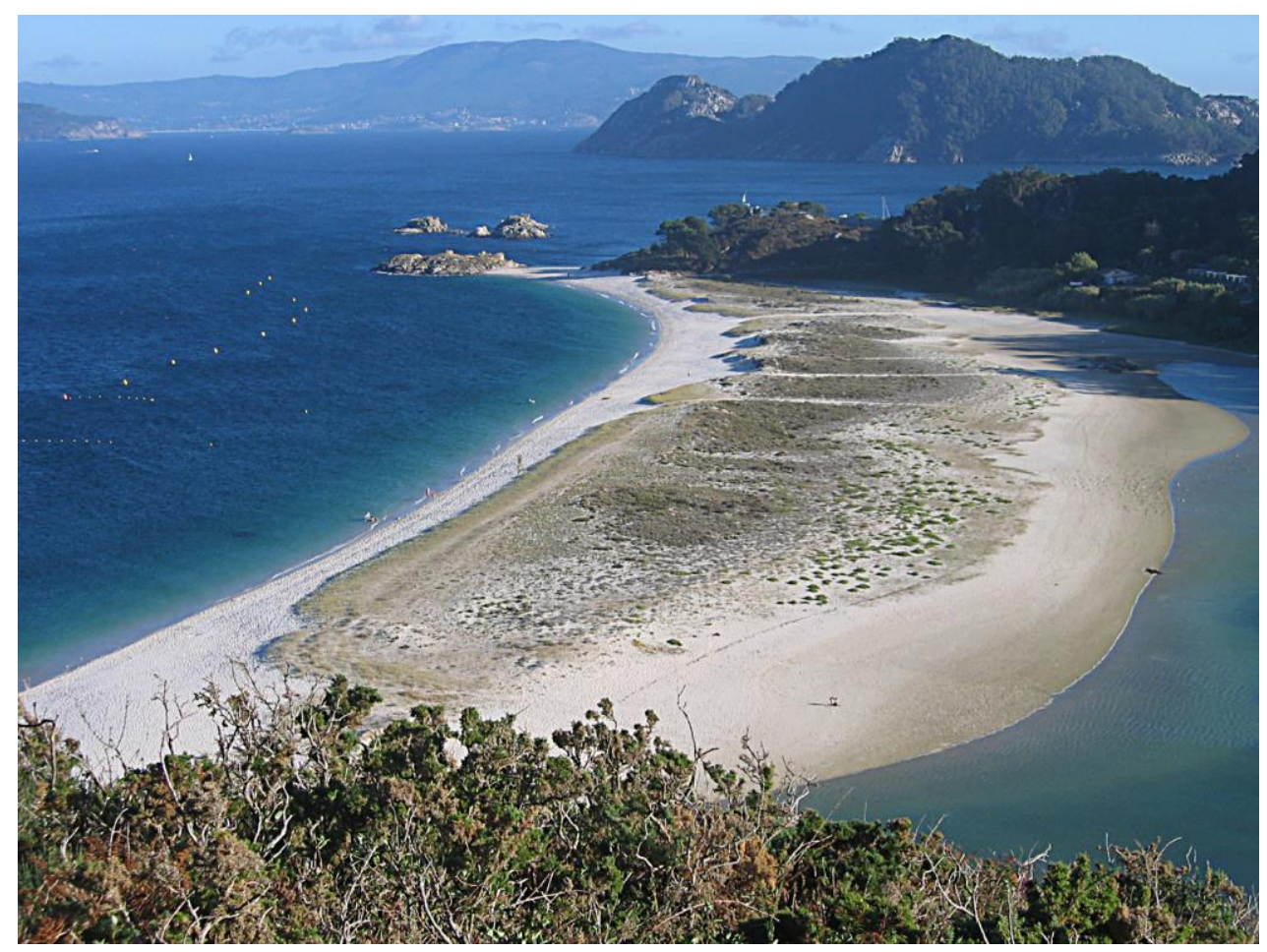

Fig. 3-Sampling site (Rodas beach, Faro island, Cies islands, PNMTIAG, Spain).

Habitat - in open dunes, on dead stalks of Helichrysum picardii var. virescens.

Known distribution - so far only known from the type locality in Cies islands (Spain).

Material examined - SPAIN. Pontevedra: Vigo, Cíes islands, Faro island, Rodas beach, 29TNG0874, $5 \mathrm{~m}$, in open dunes, on dead stalks of Helichrysum picardii var. virescens, 14 December 2010, J.B. Blanco-Dios \& A. Castro, LOU-Fungi 19745 (holotype); ibidem, 11 January 2011, J.B. Blanco-Dios, LOU-Fungi 19746.

\section{Discussion}

According to Singer (1973) and Antonin \& Noordeloos (2010), Marasmiellus ciesanus belongs to sect. Dealbati Singer, subsect. Quercini Singer, subsection created for species with pileipellis without distinct Rameales-structure, pileus and stipe pigmented and spores usually shorter than $10.5 \mu \mathrm{m}$. M. ciesanus is unique with respect to the other known Marasmiellus species by the following combination of features: (i) unusual small basidiospores, broadly ellipsoid to oblong-lacrimoid (ii) larger basidia, (iii) versiform cheilocystidia, (iv) morphologically highly variable terminal elements of the pileipellis, (v) multiform caulocystidia and (vi) specific substrata (dead stalks of Helichrysum picardii var. virescens) in coastal open dunes.

A few species among the morphologically similar species in subsect. Quercini presents unusual small spores. The closest European taxa is Gymnopus inexpectatus Consiglio, Vizzini, Antonin \& Contu (Vizzini et al. 2008). Members beloging to genus Gymnopus (Pers.) Roussel are mainly saprotrophic, growing on leaf litter of different vegetal material, rarely of a lignicolous habitat, as occurs in this species. Several works have pointed to the polyphyletic origin of Marasmiellus and Gymnopus (Moncalvo et al. 2000,2002, Mata et al. 2004, Wilson \& Desjardin 2005) and stated a major clade integrated of five well-defined subclades within gymnopoid euagarics. Gymnopus inexpectatus is characterized by a brownish ochre coloured, rusty red spotted pileus, pallescent on drying to ochraceous cream, pink cream lamellae, a rather thick insititious stipe, basidiospores 5-6 $(-7) \times 3,2-4(-4.5) \mu \mathrm{m}$ (broadly) ellipsoid to ovoid, cheilocystidia lageniform, subfusoid or subcylindrical, often rostrate, often irregular to subcoralloid, pileipellis a "special form" of Dryophila- or Rameales-structure and caulocystidia cylindrical, clavate, regular, irregular to coralloid and different substrata (dead branches of Quercus ilex) (Vizzini et al. 2008, Antonín \& Noordeloos 2010). 


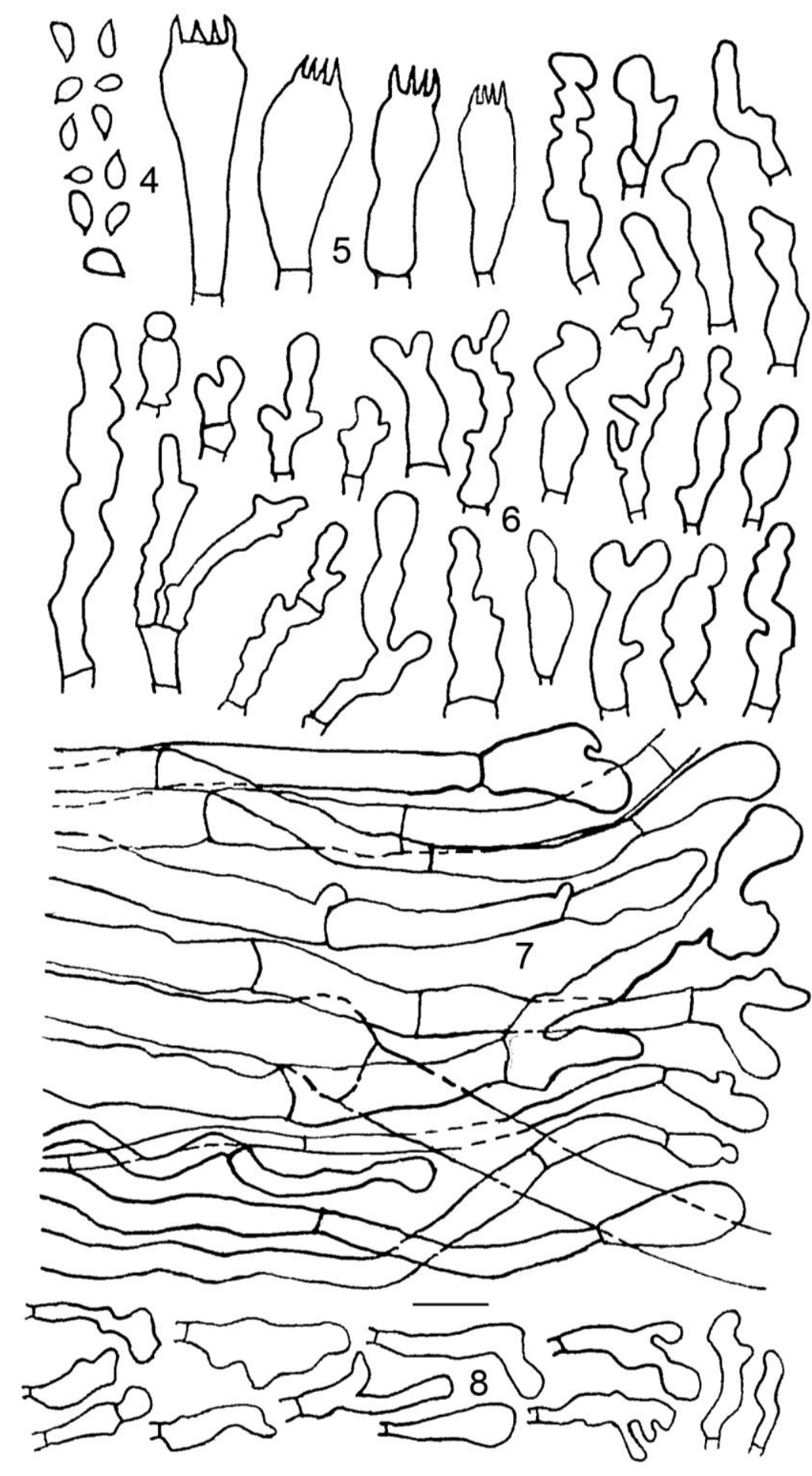

Figs 4-8-Marasmiellus ciesanus (holotype, LOU-Fungi 19745). 4. Basidiospores. 5. Basidia. 6. Cheilocystidia. 7. Pileipellis. 8. Caulocystidia. Scale bar $=10 \mu \mathrm{m}$

Among extra-European species with small spores of the same subsection, M. paraensis Singer, M. corynophloeus Singer, M. aurantiorufescens Singer, M. subolivaceomelleus Singer and M. baeosporus Singer (Singer 1973), and M. baeosporoides Singer (Singer 1989), described from South America, are morphologically similar to M. ciesanus. M. paraensis differs particularly from M. ciesanus by having spores 5.5-6 $\times 2-2.5(-3) \mu \mathrm{m}$, oblong (rarely ellipsoid), smaller basidia, cheilocystidia ventricose to clavate, even vesiculose, caulocystidia mostly cylindric, often several times constricted and even submoniliform, sometimes clavate and short capitate, and habitat on 
tropical forest litter; M. corynophloeus is characterized by basidiospores $5.5-6.7 \times 3-4 \mu \mathrm{m}$, ellipsoid to fusoid-ellipsoid, cheilocystidia clavate, more rarely ventricose, ampullaceous or flexuosus, caulocystidia normally cylindric or ventricose and habitat on leaves fallen to the ground in tropical rain forest; $M$. aurantiorufescens is different by having a pileus becoming rufous to carrot red on drying, basidiospores (4.5-) 5.5-6.7 × 2.5-2.8 $\mu \mathrm{m}$, oblong, smaller basidia, cheilocystidia clavate, ventricose or cylindric, sometimes bi-lobed or forked, caulocystidia nearly all cylindric, obtuse at the tip, the longest ones often showing cross walls and habitat on oak leaves and pine needles in mixed montane woods; M. subolivaceomelleus is distinguished by a pileus young olive-melleous, later melleous, basidiospores $5.3 \times 3 \mu \mathrm{m}$, ellipsoid, smaller basidia, cheilocystidia varying from simple hyphal outgrowths to larger and broader cauliflower-like bodies, caulocystidia filamentous or somewhat tapering upwards or downwards, sometimes with swollen apex and subglobose and habitat on coriaceous leaves in virgin rain forest; $M$. baeosporus differs especially by having basidiospores 4.7-5.2 × 2.3-2.8 $\mu \mathrm{m}$, ellipsoid, smaller basidia, cheilocystidia ventricose to subvesiculose-subclavate, caulocystidia vesiculose to ventricose, rarely ampullaceous and habitat on fallen coriaceous leaves of trees in Pacific rain forest area (Singer 1973); finally, Marasmiellus baeosporoides produces basidiospores oblong-subfusoid, 4-5.5 × 1.5$2.7 \mu \mathrm{m}$, smaller basidia, cheilocystidia subfusoid or utriform, caulocystidia similar cheilocystidia and habitat on dead branches in tropical forest (Singer 1989).

\section{Acknowledgements}

The author is grateful to Amancio Castro for providing the photographs of Marasmiellus ciesanus and technical assistance. Helena Velayos are gratefully acknowledged for kindly sending relevant literature. We express the most sincere thanks to the director and members of the Centro de Investigación Forestal de Lourizán (Consellería de Medio Rural e do Mar, Xunta de Galicia) for conserving the herbarium LOU-Fungi.

\section{References}

Antonín V, Noordeloos ME. 1993 - A monograph of Marasmius, Collybia and related genera from Europe, part 1: Marasmius, Setulipes and Marasmiellus. Libri Botanici 8, 1-229.

Antonín V, Noordeloos ME. 2010 - A monograph of marasmioid and collybioid fungi in Europe. IHW Verlag Eching, Germany, 480 pp.

Antonín V, Ryoo R, Shin H-D. 2010 - Two new marasmielloid fungi widely distributed in the Republic of Korea. Mycotaxon 112, 189-199.

Blanco-Dios JB. 2001 - Agaricales des dunes de Galice (Nord-Ouest de l'Espagne) (I): Agaricus freirei, sp. nov. Documents mycologiques 121, 27-34.

Blanco-Dios JB. 2010 - Agaricales de las dunas de Galicia (II): Campanella caesia Romagn. Tarrelos 12, 25-29.

Blanco-Dios JB. 2014 - Agaricales de las dunas de Galicia (III): una nueva variedad de Chamaemyces fracidus (Agaricaceae) encontrada en el Parque Nacional Marítimo-Terrestre das Illas Atlánticas de Galicia. Tarrelos 16, 34-36.

Contu M. 2008 - Descrizione annotata ed iconografie di Marasmiellus maritimus, una rara specie della fascia costiera olbiense (Sardegna). Bollettino Associazione Micologica ed Ecologica Romana 73-74, 62-66.

Corner EJH. 1996 - The agaric genera Marasmius, Chaetocalathus, Crinipellis, Heimiomyces, Resupinatus, Xerula, and Xerulina in Malesia. Beihefte Nova Hedwigia 111, 1-164.

Desjardin DE. 1985 - The marasmioid fungi of California. Master's Thesis, San Francisco State University, $278 \mathrm{pp}$.

Desjardin DE. 1987 - Marasmioid fungi: the genera Baeospora, Crinipellis, Marasmiellus, Marasmius, Micromphale, and Strobilurus. In: The Agaricales of California 7: Tricholomataceae. Mad River Press, Eureka. 99 pp 
Desjardin DE. 1997 - A synopsis of Marasmiellus in the southern Appalachian Mountains. Mycotaxon 65, 237-261.

Desjardin DE, Wong GJ, Hemmes DE. 1992 - Agaricales of the Hawaiian Islands. I. Marasmioid fungi: new species, new distributional records, and poorly known taxa. Canadian Journal of Botany 70, 530-542.

Grgurinovic CA. 1997 - Larger Fungi of South Australia. The Botanic Gardens of Adelaide and State Herbarium \& The Flora and Fauna of South Australia Handbooks Committee Adelaide, Adelaide.

Horak E. 1987 - Tetrapyrgos Horak. (nom. et gen. nov.) replacing Pterospora Métrod (1949: nom. preocc.). Sydowia 39, 101-103.

Kirk PM, Cannon PF, Minter DW, Stalpers JA. 2008 - Dictionary of the Fungi. 10th ed. CABI, Wallingford, $771 \mathrm{pp}$.

Mata JL, Hughes KW, Petersen RH. 2004 - Phylogenetic placement of Marasmiellus juniperinus. Mycoscience 45: 214-221.

Moncalvo J-M, Lutzoni FM, Rehner SA, Johnson J, Vilgalys R. 2000 - Phylogenetic relationships of agaric fungi based on nuclear large subunit ribosomal DNA sequences. Systematic Biology 49 (2), 278-305.

Moncalvo J-M, Vilgalys R, Redhead SA, Johnson JE, James TY, Aime MC, Hofstetter V, Verduin SJW, Larsson E, Baroni TJ, Thorn RG, Jacobsson S, Clémençon H, Miller OK. 2002 - One hundred and seventeen clades of euagarics. Molecular Phylogenetics and Evolution 23(3), 357-400.

Murrill WA. 1915 - Agaricaceae (pars). North American Flora 9(4), 237-255, 286-296.

Pegler DN. 1977 - A preliminary agaric flora of East Africa. Kew Bulletin Add. Ser. VI. Her Majesty's Stationery Office, London, 620 pp.

Pegler DN. 1983 - Agaric flora of the Lesser Antilles. Kew Bulletin Add. Ser. IX. Her Majesty's Stationery Office, London, $672 \mathrm{pp}$.

Pegler DN. 1986 - Agaric flora of Sri Lanka. Kew Bulletin Add. Ser. XII. Her Majesty's Stationery Office, London, $519 \mathrm{pp}$.

Pérez-De-Gregorio MA, Vizzini A, Contu M, Roqué C, Ercole E. 2011 - Marasmiellus celebanticus (Agaricales, Omphalotaceae), a new species of Marasmiellus sect. Candidi collected in the Mediterranean area. Phytotaxa 25, 49 - 59.

Retnowati A. 2012 - Taxonomic study of the genus Marasmiellus Murrill in Java and Bali. Master's thesis. Fakultas matematika dan ilmu pengetahuan alam. Universitas Indonesia. 162 $\mathrm{pp}$

Singer R. 1973 - The genera Marasmiellus, Crepidotus and Simocybe in the Neotropics. Beihefte Nova Hedwigia 44, 1-517.

Singer R. 1976 [1975] - The neotropical species of Campanella and Aphyllotus with notes on some species of Marasmiellus. Nova Hedwigia 26 (4), 847-896.

Singer R. 1986 - The Agaricales in modern taxonomy. 4th ed. Koenigstein: Koeltz Scientific Book. $981 \mathrm{pp}$

Singer R. 1989 - New taxa and new combinations of Agaricales (Diagnoses fungorum novorum Agaricalium IV). Fieldiana Botany new ser. 21, 1-133.

Takahashi H, Degawa Y. 2006 - Two new Marasmiellus species found on the bark of living coniferous and broad-leaved trees in Japan. Mycoscience 47, 257-262. Doi: 10.1007/s10267006-0302-z

Thiers B. 2015 - Index Herbariorum: A global directory of public herbaria and associated staff. New York Botanical Garden's Virtual Herbarium. http://sweetgum.nybg.org/ih/ (continuously updated).

Vizzini A, Consiglio G, Antonin V, Contu M. 2008 - A new species within the Gymnopus dryophilus complex (Agaricomycetes, Basidiomycota) from Italy. Mycotaxon 105, 43-52.

Wilson AW, Desjardin DE. 2005 - Phylogenetic relationships in the gymnopoid and marasmioid fungi (Basidiomycetes, euagarics clade). Mycologia 97, 667-679. 